\title{
Prioritizing Pain: An Analysis of the Policy Environment Affecting Patients Suffering From Chronic Pain Across Europe
}

\author{
Thomas Tölle ${ }^{1}$, Jean-Pascal Roussy², Laura Campo ${ }^{3}$, Craig Beck², Stefan Wilhelm ${ }^{3}$, Tim Wilsdon ${ }^{4} \&$ Serge Perrot $^{5}$ \\ ${ }^{1}$ Department of Neurology, Technische Universität München; ${ }^{2}$ Pfizer Inc; ${ }^{3}$ Eli Lilly \& Company; ${ }^{4}$ Charles River Associates; ${ }^{5}$ Centre de la Douleur, \\ Hôpital Cochin, Faculté Paris Descartes
}

\section{Background and introduction}

- There are 100 million people with chronic pain in Europe, but despite the large and increasing burden it has not received sufficient policy attention

- To date there has been little research to identify critical areas of need in the policy environment, or what actions are required to support treatment and care for patients

\section{Aim}

- The aim of this study was to conduct a comprehensive analysis of public health policies and non-governmental initiatives in chronic pain across seven European countries: France, Germany, Italy, Poland, Spain, Sweden and the UK

\section{Methodology}

- We developed a chronic pain policy patient journey framework that includes key components to structure the research and analysis (Figure 1)

- A comprehensive literature review was undertaken to populate the policy framework that included government publications, academic literature and grey literature

- We evaluated the level of policy development in each component against standardized evaluation criteria (Figure 2)

Figure 1. Chronic pain patient journey framework

\begin{tabular}{|c|c|c|c|c|}
\hline Policy area & \multicolumn{4}{|c|}{ Policy component } \\
\hline $\begin{array}{l}\text { International and } \\
\text { National Pain } \\
\text { Strategy }\end{array}$ & $\begin{array}{l}\text { International } \\
\text { organizations } \\
\text { agenda }\end{array}$ & $\begin{array}{l}\text { National pain } \\
\text { policies }\end{array}$ & & \\
\hline $\begin{array}{l}\text { Awareness and } \\
\text { recognition }\end{array}$ & $\begin{array}{l}\text { Recognition as a } \\
\text { chronic condition }\end{array}$ & $\begin{array}{l}\text { Public and patient } \\
\text { awareness }\end{array}$ & $\begin{array}{l}\text { Prevention and self } \\
\text { management }\end{array}$ & $\begin{array}{l}\text { Healthcare } \\
\text { professional } \\
\text { awareness and } \\
\text { education }\end{array}$ \\
\hline $\begin{array}{l}\text { Coordination and } \\
\text { diagnosis }\end{array}$ & Referral system & Diagnosis & $\begin{array}{l}\text { Treatment } \\
\text { guidelines }\end{array}$ & $\begin{array}{l}\text { Management of } \\
\text { opioid use }\end{array}$ \\
\hline $\begin{array}{l}\text { Access to specialist } \\
\text { treatment }\end{array}$ & Regulatory approval & $\begin{array}{l}\text { HTA and Pricing \& } \\
\text { reimbursement }\end{array}$ & Funding and access & \\
\hline Ongoing support & Ongoing care & $\begin{array}{l}\text { Support } \\
\text { programmes } \\
\text { (medical, social, } \\
\text { employer) }\end{array}$ & Research & Advocacy support \\
\hline
\end{tabular}

Figure 2. Criteria for evaluation of policy components

\begin{tabular}{|l|l|l|}
\hline $\begin{array}{l}\text { Established pain- } \\
\text { specific policies } \\
\text { and programs }\end{array}$ & $\begin{array}{l}\text { Medium } \\
\text { Buader policies } \\
\text { with implications } \\
\text { on pain } \\
\text { Pain-specific } \\
\text { policies are not } \\
\text { uniformly } \\
\text { implemented } \\
\text { No policies in } \\
\text { place but there is } \\
\text { ongoing debate }\end{array}$ \\
\hline
\end{tabular}

\section{Results}

- At EU level, there is increasing recognition of chronic pain driven by Council of the EU, Health Ministers Meeting and the European Commission

- In most countries pain is not prioritized through coordinated national plans but targeted policies and programs exist (Figure 3). In Spain, for example, a strategy for the management of pain under the Spanish National Health System was launched in 2014

- Patient advocacy groups are key drivers for awarenessrelated policy change and implementation, however these often receive limited government support

- While clinical guidelines on diagnosis, treatment and management have been established, application is often limited, and many countries report delays in diagnosis and suboptimal pain management. Dedicated centres supporting patients' long-term care varies across regions and countries

- National pain registries are not widely established, hindering efforts to demonstrate the medical unmet needs and hampering evidence-based informed policy advocacy

Figure 3. Summary of policy analysis across the seven countries

\begin{tabular}{|c|c|c|c|c|c|c|c|c|}
\hline Area & Policy component & $y$ & & $(1)$ & 0 & 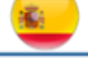 & $\theta$ & $\frac{2 \pi}{2}$ \\
\hline \multirow{4}{*}{ 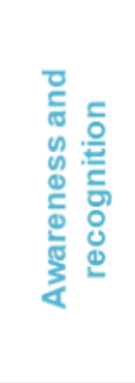 } & $\begin{array}{l}\text { Recognition of CLBP as } \\
\text { chronic condition }\end{array}$ & & O & & & O & & O \\
\hline & Public and patient awareness & 0 & 0 & 0 & 0 & 0 & 0 & O \\
\hline & $\begin{array}{l}\text { Prevention and self- } \\
\text { management }\end{array}$ & 0 & O & O & & O & O & P \\
\hline & $\begin{array}{l}\text { HCP awareness and } \\
\text { education }\end{array}$ & & O & O & & O & 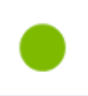 & 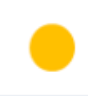 \\
\hline \multirow{4}{*}{ 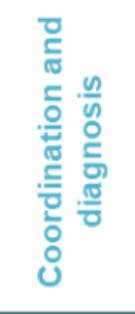 } & Referral system & O & O & 0 & & 0 & 0 & 0 \\
\hline & Diagnosis & 0 & O & O & 0 & 0 & 0 & O \\
\hline & Treatment guidelines & O & O & O & 0 & O & 0 & 0 \\
\hline & Management of opioid use & 0 & O & O & 0 & 0 & 0 & 0 \\
\hline \multirow{3}{*}{ 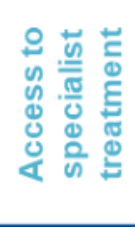 } & Regulatory approval & 0 & O & O & 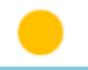 & 0 & 0 & O \\
\hline & HTA and P\&R & 0 & O & O & 0 & 0 & O & O \\
\hline & Funding and access & 0 & O & O & ( & 0 & 0 & D \\
\hline \multirow{4}{*}{ 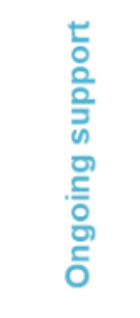 } & Ongoing care (monitoring) & O & O & O & & C & 0 & \\
\hline & $\begin{array}{l}\text { Support programmes } \\
\text { (medical, social, employer) }\end{array}$ & & & & & & & \\
\hline & Research & 0 & O & O & O & O & O & O \\
\hline & Advocacy support & 0 & O & O & & C & O & 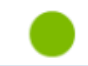 \\
\hline
\end{tabular}

\section{Conclusion}

- Given the challenges facing patients, sharing best practices is vital. Governments should prioritize chronic pain; developing a clear policy agenda to address the lack of awareness amongst patients, healthcare professionals and payers

- Policy should ensure patients play an important role in the assessment of treatments and that there are appropriate provisions in value assessment methodology in order to ensure widespread access to specialized treatments 